\author{
Pawel BALON ${ }^{1}$ \\ Andrzej ŚWIĄTONIOWSKI ${ }^{2}$ \\ Edward REJMAN ${ }^{3}$ \\ Bartłomiej KIEŁBASA ${ }^{4}$ \\ Robert SMUSZ ${ }^{5}$ \\ Janusz SZOSTAK ${ }^{6}$ \\ Lukasz KOWALSKI ${ }^{7}$ \\ Natalia BALON ${ }^{8}$ \\ Jacek CIEŚLIK ${ }^{9}$
}

\title{
ZASTOSOWANIE CIENKOŚCIENNYCH KONSTRUKCJI INTEGRALNYCH W LOTNICTWIE NA PRZYKŁADZIE PROJEKTU SAT-AM
}

\begin{abstract}
Konstrukcje samolotów są poddawane w trakcie lotu działaniu różnych składowych stanu obciążenia. Każde zadanie w czasie lotu składa się z szeregu manewrów, które generują różne obciążenia samolotu, zarówno pod względem wartości, jak i kierunku ich działania. Wysoki poziom trwałości i niezawodności jest podstawowym, ścisłym wymogiem dla współczesnych konstrukcji lotniczych. Oznacza to, że podczas projektowania statku powietrznego należy wziąć pod uwagę wiele nierzadko sprzecznych ze sobą ograniczeń. Najważniejszym z nich jest masa konstrukcji, która ma decydujący wpływ zarówno na właściwości lotne i techniczne, jak i na ekonomikę eksploatacji. To sprawia, że samolot jest jednym z najbardziej złożonych produktów technicznych. Nowoczesne konstrukcje samolotów, a ściślej ich elementy nośne, są prawie wyłącznie wykonane jako cienkościenne, które spełniają postulat zminimalizowania masy kon-
\end{abstract}

\footnotetext{
1 Autor do korespondencji: Paweł Bałon, SZEL-TECH Szeliga Grzegorz, ul. Sołtyka 16, 39-300 Mielec, Akademia Górniczo-Hutnicza w Krakowie, al. Mickiewicza 30-B2, 30-059 Kraków, e-mail: p.balon@szel-tech.pl, ORCID: 0000-0003-3136-7908.

2 Andrzej Świątoniowski, Akademia Górniczo-Hutnicza w Krakowie, al. Mickiewicza 30-B2, 30-059 Kraków.

${ }^{3}$ Edward Rejman, Politechnika Rzeszowska im. Ignacego Łukasiewicza, al. Powstańców Warszawy 12, 35-959 Rzeszów.

${ }^{4}$ Bartłomiej Kiełbasa, SZEL-TECH Szeliga Grzegorz, ul. Sołtyka 16, 39-300 Mielec.

${ }^{5}$ Robert Smusz, Politechnika Rzeszowska im. Ignacego Łukasiewicza, al. Powstańców Warszawy 12, 35-959 Rzeszów.

${ }^{6}$ Janusz Szostak, Akademia Górniczo-Hutnicza w Krakowie, al. Mickiewicza 30-B2, 30-059 Kraków.

${ }^{7}$ Łukasz Kowalski, Akademia Górniczo-Hutnicza w Krakowie, al. Mickiewicza 30-B2, 30-059 Kraków.

${ }^{8}$ Natalia Bałon, SZEL-TECH Szeliga Grzegorz, ul. Sołtyka 16, 39-300 Mielec.

9 Jacek Cieślik, Akademia Górniczo-Hutnicza w Krakowie, al. Mickiewicza 30-B2, 30-059 Kraków.
} 
strukcji. Szeroko rozpowszechnione są systemy, w których pokrycie jest wzmocnione elementami wzdłużnymi i poprzecznymi, zapewniając wymaganą sztywność i wytrzymałość całości systemu. Podczas gdy miejscowa utrata stateczności pokrycia jest dopuszczalna w warunkach obciążenia roboczego, przekroczenie poziomów obciążenia krytycznego elementów szkieletu konstrukcyjnego (ramy, podłużnice, wręgi) jest praktycznie równoznaczne ze zniszczeniem konstrukcji. Wskazane czynniki wymuszają ciągłe doskonalenie zarówno metod projektowania, jak i rozwiązań konstrukcyjnych w lotnictwie. Rozwój inżynierii materiałowej i ciągłe doskonalenie procesów technologicznych nie pozostają bez znaczenia dla skuteczności tych pomysłów.

Dyscypliny te pozwalają konstruować geometrycznie złożone integralne struktury, które stwarzają możliwość nie tylko bardziej racjonalnego wykorzystania właściwości materiału, ale także, poprzez ich odpowiednie ukształtowanie, znacznie zwiększają dopuszczalne obciążenia konstrukcji nośnej. Główną zaletą przy projektowaniu części integralnych jest oszczędność ekonomiczna, uzyskana w wyniku wyeliminowania lub ograniczenia operacji montażowych. Gęsto żebrowane elementy pokrycia wykonane w tej technologii należą do elementów konstrukcji nośnej, które zmniejszają masę i podnoszą parametry wytrzymałościowe konstrukcji nośnej. Zmniejszając grubość pokrycia i jednocześnie wprowadzając gęsto usztywniające elementy podłużne, można uzyskać konstrukcję o znacznie wyższych obciążeniach krytycznych, a w konsekwencji bardziej korzystny rozkład gradientów i poziomów naprężeń, co bezpośrednio przyczynia się do zwiększenia trwałości zmęczeniowej. W artykule podjęto próbę oceny wprowadzenia nowych technologii wykonania konstrukcji płatowców dla podniesienia ich walorów wytrzymałościowych, aerodynamicznych oraz masowych.

Słowa kluczowe: konstrukcje cienkościenne, konstrukcje integralne, frezowanie z dużą prędkością skrawania, HSM

\section{Wprowadzenie}

Konstrukcje lotnicze w trakcie eksploatacji są poddawane szerokiemu spektrum obciążeń. Każde zadanie wykonywane w locie składa się z szeregu manewrów, które generują odmienne rodzaje obciążenia samolotu, zarówno co do wartości, jak i kierunku ich działania. Rygorystycznym wymogiem, stawianym współczesnym konstrukcjom lotniczym jest wysoka trwałość i niezawodność. Wymóg ten sprawia, że $\mathrm{w}$ trakcie procesu projektowania samolotu należy uwzględniać wiele nierzadko sprzecznych warunków. Najistotniejszy parametr stanowi tutaj masa konstrukcji, mająca decydujący wpływ zarówno na właściwości lotno-techniczne, jak i ekonomiczność eksploatacji. Sprawia to, iż statki powietrzne są jednymi z najbardziej złożonych systemów współczesnej techniki.

Obecnie konstrukcje lotnicze, a ściślej - ich struktury nośne wykonuje się niemal wyłącznie jako cienkościenne, które w doskonałym stopniu spełniają postulat minimalizowania masy konstrukcji. W lotnictwie szeroko rozpowszechnione są cienkościenne konstrukcje, które są wzmacniane elementami wzdłużnymi oraz poprzecznymi, co zapewnia wymaganą sztywność i wytrzymałość. $\mathrm{O}$ ile w warunkach obciążenia eksploatacyjnego dopuszczalna jest lokalna utrata stateczności pokrycia, to przekroczenie krytycznych poziomów obciążenia konstrukcji (wręgi, podłużnice) jest praktycznie równoznaczne ze zniszczeniem konstrukcji. 
Wspomniana specyfika wymusza ciągłe ulepszanie zarówno metod projektowania, jak i doskonalenie rozwiązań konstrukcyjnych struktur lotniczych. Nie bez znaczenia dla poprawy skuteczności tych zamysłów jest rozwój nauki o materiałach oraz ciągłe usprawnianie procesów technologicznych. Dyscypliny te pozwalają na konstruowanie złożonych geometrycznie integralnych struktur, które stwarzają możliwości nie tylko bardziej racjonalnego wykorzystania charakterystyk materiałowych, lecz również poprzez ich odpowiednie kształtowanie, zwiększają w sposób znaczący właściwości mechaniczne struktury nośnej. Zaletą o pierwszorzędnym znaczeniu, przemawiającą za stosowaniem konstrukcji integralnych, jest oszczędność ekonomiczna, zyskiwana wskutek eliminacji lub ograniczenia operacji montażowych. Do kategorii elementów struktury nośnej, które nie zmniejszając lub wręcz pomniejszając masy, podwyższają parametry wytrzymałościowe konstrukcji nośnej, należą gęsto żebrowane elementy pokrycia. Zmniejszając grubość pokrycia oraz jednocześnie wprowadzając dostatecznie gęsto usztywniające elementy wzdłużne i poprzeczne, można uzyskać strukturę o zdecydowanie wyższych wartościach obciążeń krytycznych, a w konsekwencji korzystniejszy rozkład gradientów i poziomów naprężeń, co w prostej linii przekłada się na wzrost trwałości zmęczeniowej.

\section{Sposoby podwyższania wytrzymałości struktur cienkościennych}

Cienkościenne struktury nośne konstrukcji lotniczych są poddawane złożonym stanom obciążenia. Aby zgodnie ze stosownymi przepisami spełniać wymogi stawiane statkowi powietrznemu, należy zapewnić mu odpowiednią sztywność oraz wytrzymałość. Jedną z możliwych form osiągania celu jest:

- zastosowanie pokrycia o zwiększonej grubości, co prowadzi do wzrostu masy konstrukcji oraz nieefektywnego wykorzystania właściwości materiału,

- zastosowanie struktur kompozytowych (w tym również przekładkowych), co wiąże się z koniecznością zastosowania technologii Automated Tape Laying (ATL) zapewniającej powtarzalność właściwości mechanicznych konstrukcji (preimpregnatów cienkowarstwowych układanych w warstwy bądź zestawy warstw za pomocą innowacyjnej technologii Automatic Tape Laying),

- wzmacnianie pokrycia za pomocą elementów usztywniających. Rozwiązanie takie jest obecnie szeroko stosowane, bowiem pozwala na efektywne wykorzystanie materiału oraz właściwości geometrii struktury.

Wybór wersji jest uzależniony od wielu czynników, spośród których jednym z najistotniejszych jest poziom obciążenia doprowadzający konstrukcję do utraty lokalnej stateczności elementów pokrycia.

Jednym z podstawowych elementów współcześnie projektowanych struktur nośnych płatowca jest pokrycie. W każdej formie konstrukcja składa się z cien- 
kościennego pokrycia oraz elementów usztywniających, wzdłużnych i poprzecznych. Jedną $\mathrm{z}$ dominujących form obciążenia stanowi ściskanie wywoływane równomiernie rozłożonym obciążeniem ciągłym przykładanym do brzegu płyty, równolegle do osi podłużnic (rys. 1.).

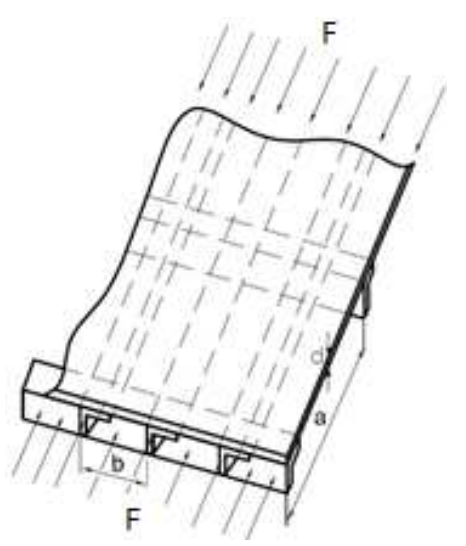

Rys. 1. Schemat ściskanej struktury pokrycia wzmacnianej podłużnicami i wręgami

Pokrycie samolotu, wzmacniane elementami wzdłużnymi i poprzecznymi, zostaje dzielone na szereg elementów, z których każdy wyodrębniony fragment można traktować jako płytę podpartą (najczęściej przegubowo) na czterech brzegach. Sukcesywnie zwiększane obciążenie wywołuje stany naprężenia przedstawione na rys. 2-4.

Gdy $F<F k r$, pokrycie nie utraci stateczności i w całym obszarze płyty pojawia się jednorodny stan naprężenia:

$$
\sigma_{p u d l}=\sigma_{\text {stpukT }}=\frac{F}{\Sigma\left(A_{p o d l}+A_{p o k r}\right)},
$$

gdzie: $\Sigma\left(A_{\text {podł }}+A_{\text {pokr }}\right)-$ suma powierzchni podłużnych oraz pokrycia, $F-$ obciążenie.

Zwiększanie obciążenia doprowadza do pojawienia się stanu krytycznego. Po jego przekroczeniu konstrukcja zmienia swoją pierwotną formę geometryczną, co powoduje wystąpienie odmiennego stanu naprężeń w stosunku do pierwotnego. Poszczególne fazy zmiany stanu naprężenia przedstawiono na rys. 2-4 $[1,2]$.

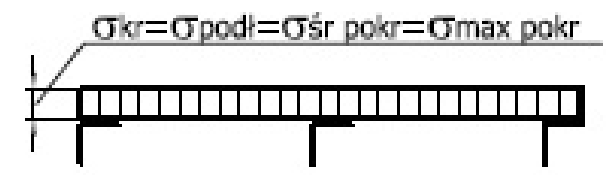

Rys. 2. Stan naprężenia w ściskanej płycie przed utratą stateczności 
Zwiększanie siły F wywołuje wzrost naprężenia w podłużnicach i elementach pokrycia w tzw. strefie współpracującej w pobliżu podłużnic, które nie utraciły stateczności. W elementach, które utraciły stateczność, naprężenia pozostają na poziomie $\sigma_{\text {KR }}$.

Rys. 3. Stan naprężenia w przekroju poprzecznym płyty po utracie stateczności

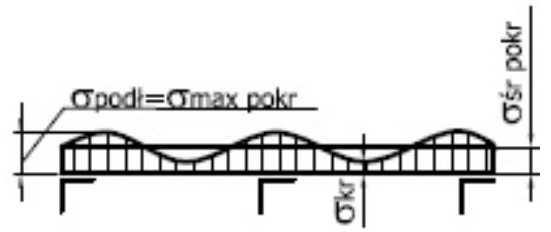

Przy pewnym poziomie siły $\mathrm{F}$ i wzroście jej do takiej wartości, że naprężenia $\mathrm{w}$ podłużnicach i przyległych do nich obszarach pokrycia staną się równe naprężeniom granicznym, podłużnice również tracą stateczność i płyta ulega zniszczeniu.

Rys. 4. Rozkład naprężeń w przekroju żebrowanej płyty w warunkach nośności granicznej

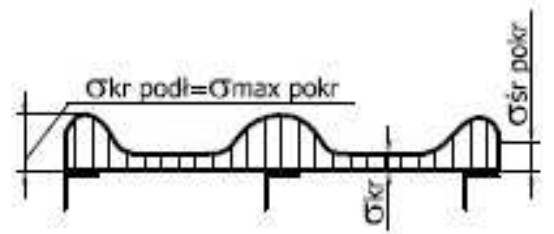

Przedstawiona jakościowa ocena stanu naprężenia konstrukcji pokrycia wskazuje, jak istotne znaczenie w zwiększeniu obciążalności konstrukcji odgrywają elementy wzmacniające typu podłużnice. We współczesnych konstrukcjach lotniczych najczęściej są one wykonywane jako elementy integralne z pokryciem, tworzone na drodze obróbki ubytkowej. Odpowiedni dobór technologii ich wykonania, zapewnienie dokładności wymiarowo-kształtowej, jak również wysokiej wydajności procesu obróbkowego stanowi jeden z podstawowych problemów, jakie należy rozwiązać we współczesnej technologii wytwarzania. Zagadnieniom tym została poświęcona dalsza część opracowania [3-5].

\section{Technologiczne metody zwiększenia obciążalności konstrukcji lotniczych i zmniejszenia ich masy - badania własne}

Zastosowanie konstrukcji integralnych pozwala na zmniejszenie masy konstrukcji i pracochłonności ich wykonania ze względu na uniknięcie stosowania elementów łączących oraz przewymiarowania lokalnego konstrukcji. Pociąga to jednak za sobą wprowadzanie technologii umożliwiających kształtowanie cienkościennych elementów nośnych. We współczesnym lotnictwie integralne części samolotów ze stopów aluminium i tytanu są wykonywane najczęściej metodą obróbki wiórowej z półfabrykatów takich jak płyty walcowane na zimno lub na gorąco. 
Jednak ciągłe dążenie do obniżenia kosztów produkcji w przemyśle lotniczym wymusiło stworzenie nowych metod i strategii obróbki elementów konstrukcyjnych samolotów i śmigłowców poprzez wprowadzenie elementów integralnych.

Konstrukcje blaszane i nitowane były szeroko stosowane w XX w. Ostatnia dekada XX i początek XXI w. to dynamiczny rozwój integralnych, jak i kompozytowych części. Zespoły montażowe zawierały dużą liczbę części, co zwiększało pracochłonność ich wykonania oraz ciężar konstrukcji. Sytuację tą zmienia m.in. zastosowanie metody obróbki High Speed Machining, która to technologia umożliwia wykonanie integralnych cienkościennych konstrukcji z pełnych półfabrykatów. W celu wdrożenia tego procesu w warunkach produkcyjnych przeprowadzono badania własne nad technologią HSM w warunkach przemysłowych zarówno na próbkach, jak również konkretnych wyrobach. Obiektem badań była belka samolotu, która w klasycznym wykonaniu składa się z ok. 30 części (rys. 5.). Wykorzystanie obróbki HSM umożliwiło wykonanie takich elementów, jak i podobnych, np. wręga samolotu, jako jednej integralnej części.

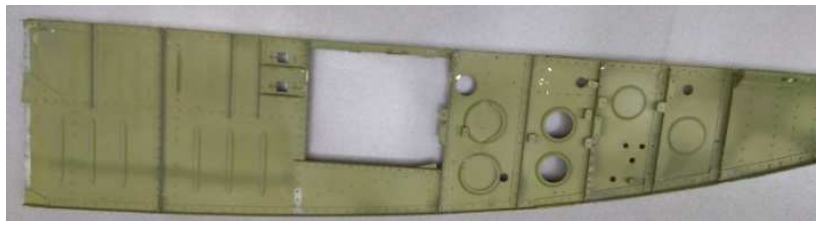

Rys. 5. Belka samolotu wykonana $\mathrm{w}$ technologii gięcia i nitowania struktur blaszanych

Obróbka HSM umożliwia wykonywanie integralnych elementów, zachowując jednocześnie tak ważne cechy konstrukcji lotniczych, jakimi są niski ciężar oraz cienkie ścianki zapewniające odpowiednią wytrzymałość i wysoką sztywność. Ważnym zagadnieniem przy stosowaniu obróbki HSM, szczególnie w obróbce zgrubnej cienkich ścianek i żeber, jest właściwy rozkład naddatku obróbkowego, tak aby zapewnić im odpowiednią sztywność giętną, co wpływa na dokładność obróbki i chropowatość powierzchni.

W celu uzyskania dużej wydajności obróbki, jak również chropowatości powierzchni i dokładności wymiarowej wytwarzanych elementów zachodzi konieczność prowadzenia obróbki z dużymi prędkościami skrawania i wysokimi prędkościami obrotowymi wrzeciona. We własnych badaniach realizowano to z prędkością skrawania $v_{c}$ ok. $850 \mathrm{~m} / \mathrm{min}$ oraz prędkością obrotową narzędzia $n=48000 \mathrm{obr} . / \mathrm{min}$. Powodowało to wystąpienie małych sił skrawania oraz małych odkształceń, umożliwiając uzyskanie wymaganej dokładności wymiarowej i kształtowej przedmiotu obrabianego.

W prowadzonych badaniach stwierdzono, że przy obróbce wykończeniowej ścianek o grubości poniżej $1,5 \mathrm{~mm}$ dla uzyskania odpowiedniej dokładności istotnym czynnikiem jest szerokość warstwy skrawanej $a_{p}$ mierzona wzdłuż osi frezu, która nie powinna przekroczyć wartości $6 \mathrm{~mm}$ dla ścianek o wysokości do $75 \mathrm{~mm}$. 
Podczas obróbki wykończeniowej naroży, w przypadku gdy stosunek wysokości ścianki do promienia naroża jest duży, należy:

- zastosować narzędzie o możliwie dużej średnicy (mniejszy stosunek L/D),

- wykorzystać narzędzie o mniejszej średnicy do obróbki ostatecznej.

Podczas wykonywania części o grubości ścianki ok. 0,6 mm, zalecane jest wykorzystanie narzędzi diamentowych, ze względu na możliwość uzyskania powierzchni obrabianej o chropowatości $R a$ ok. $0,2 \mu \mathrm{m}$ oraz redukcję drgań pogarszających falistość powierzchni i mogących uszkodzić narzędzie. Diamentowe narzędzia charakteryzują się małym zużyciem, posiadają dużą trwałość i zapewniają odpowiednią jakość powierzchni. Kluczowym wskaźnikiem doboru parametrów skrawania, oprócz zapewnienia wymaganej chropowatości powierzchni i dokładności wymiarowo-kształtowej, jest uzyskanie odpowiedniej wydajności obróbki. Miarą tego jest wskaźnik wydajności obróbki MMR (Material Removal Rate), który będzie decydował o celowości zastosowania metody obróbki HSM dla danej części.

W celu ukazania możliwości zastosowania technologii HSM w konstrukcjach lotniczych wykonano tą metodą belkę samolotu. Na rysunku 5. pokazano belkę wykonaną w technologii klasycznej, zaś na rys. 6. oraz 7. zaprezentowano belkę wykonaną w technologii HSM. Podzespół ten został zamontowany zamiennie w kadłubie samolotu, spełniając wszystkie wymagania konstrukcyjne i montażowe.

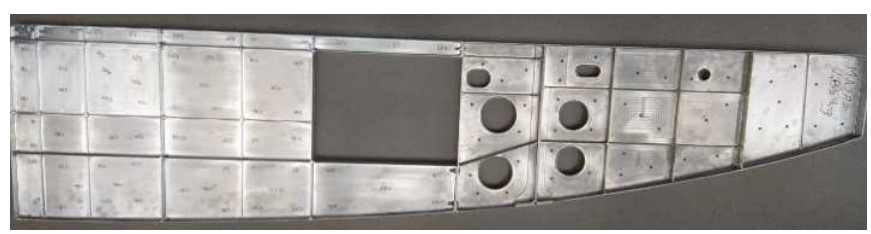

Rys. 6. Belka samolotu (struktura cienkościenna) wykonana w technologii frezowania HSM

Rys. 7. Obróbka belki wzdłużnej metodą HSM

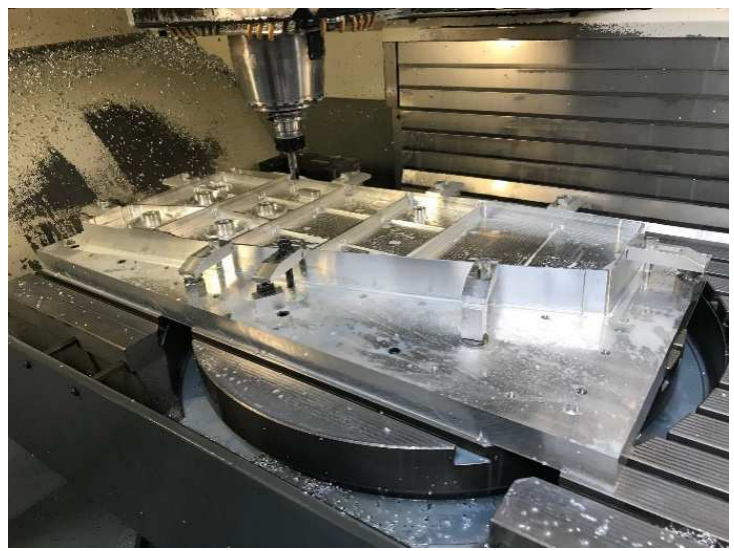


Frezowanie z dużą prędkością skrawania HSM (High Speed Machining) jest stosowane w przemyśle lotniczym, szczególnie do obróbki stopów aluminium $[6,7]$. Czynnikiem odróżniającym HSM od innych technik frezowania jest taki dobór parametrów skrawania - szerokości frezowania, głębokości skrawania, posuwu oraz prędkości skrawania - aby zapewnić dobrą jakość powierzchni oraz dokładność wymiarów i kształtów przedmiotu obrabianego, a równocześnie uzyskać wysoką wydajność obróbki, skracając w ten sposób czas wytwarzania elementów integralnych [8]. Opisuje to wzór (2), gdzie: $a_{e}$ - szerokość warstwy skrawanej,$a_{p}$ - głębokości skrawania, $v_{f}$ - prędkość posuwu [9]:

$$
Q=\frac{a_{e} \cdot a_{\mathrm{p}}-V_{f}}{1000}\left[\frac{\mathrm{cm} \mathrm{m}^{3}}{\min }\right] .
$$

Wprowadzenie metody HSM umożliwia wykonywanie z pełnego materiału bardzo skomplikowanych integralnych części lotniczych o cienkich ściankach $[10,11]$. Obecnie w projektowaniu struktury samolotów dąży się do tego, aby składał się on głównie z elementów integralnych, które we wcześniej stosowanych technologiach były wytwarzane poprzez łączenie części składowych za pomocą spawania, zgrzewania lub nitowania. Można do tej grupy zaliczyć żebra, podłużnice, dźwigary i wręgi, a także pokrycia kadłuba i skrzydła. Po frezowaniu części te są montowane w większe zespoły lub kompletne wyroby. Głównym celem stosowania opisanej technologii w konstrukcjach lotniczych jest, oprócz zapewnienia spełnienia kryterium funkcjonalności, uzyskanie jak najlepszego współczynnika stosunku wytrzymałości do ciężaru konstrukcji.

Stosowanie dużych prędkości obróbki skrawaniem umożliwia ekonomiczne wytwarzanie elementów integralnych, poprzez skracanie czasu wykonania tych części, ale również poprawia jakość powierzchni obrabianej w stosunku do klasycznych sposobów obróbki $[9,12]$.

Jak wspomniano wcześniej, jednym z podstawowych czynników decydujących o wprowadzeniu metody HSM w przemyśle lotniczym jest wydajność procesu skrawania $Q\left[\mathrm{~mm}^{3} / \mathrm{min}\right]$, zależna od głębokości skrawania $a_{p}$, szerokości warstwy skrawanej $a_{e}$, posuwu na ostrze $f_{z}$, liczby ostrzy narzędzia $z_{n}$ oraz prędkości obrotowej narzędzia $n$. W dążeniu do maksymalnej wydajności procesu skrawania należy wziąć pod uwagę inne niekorzystne zjawiska pojawiające się w procesie obróbkowym. Stosowanie nadmiernych parametrów skrawania, zwłaszcza posuwu i głębokości skrawania, powoduje wystąpienie niekorzystnego zjawiska, jakim są drgania samowzbudne (chatter).

Zakresy dopuszczalnej, stabilnej pracy obrabiarki są prezentowane za pomocą tzw. krzywej workowej przedstawiającej zależność głębokości skrawania od prędkości obrotowej narzędzia dla ustalonych pozostałych parametrów procesu.

Prowadzone badania własne potwierdziły niebezpieczeństwo wystąpienia drgań samowzbudnych przy nieodpowiednim doborze parametrów skrawania względnie błędnej strategii obróbki, szczególnie ze względu na dobór ścieżki 
obróbkowej narzędzia. Najczęściej w takich przypadkach technolodzy próbują zredukować obroty wrzeciona. Według naszej oceny lepsze efekty można uzyskać, odpowiednio definiując postać półfabrykatu tak, aby jego kształt i wymiary były możliwie jak najbardziej zbliżone do wymiarów gotowej części. Ścieżka przebiegu narzędzia podczas obróbki wykończeniowej, szczególnie przy obróbce dużych powierzchni płaskich powinna być tak ukształtowana, aby naddatek na obróbkę był usuwany w pierwszej kolejności w pobliżu punktu centralnego płyty, zaś na końcu - przy jej obrzeżach.

Właściwy dobór parametrów skrawania zapewnia falistość powierzchni obrabianej dopuszczalną dla tej klasy wyrobów. Stosowanie frezowania szybkiego zarówno przy obróbce zgrubnej, jak i wykończeniowej znacząco skraca czasy maszynowe obróbki, co jest istotnym aspektem ekonomicznym [9, 13].

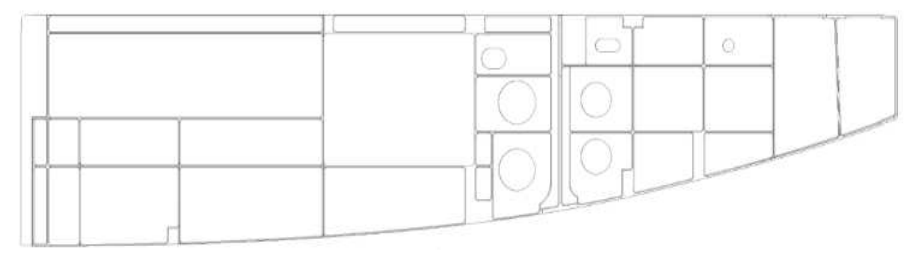

Rys. 8. Geometria belki samolotu z usztywnieniami poprzecznymi i podłużnymi

Dla porównania wyników prowadzonych badań własnych, na rys. 8. pokazano belkę samolotu wykonaną w technologii klasycznej oraz technologii frezowania HSM.

\section{Zalecenia technologiczne dla stosowania technologii HSM w kształtowaniu konstrukcji lotniczych}

Frezowanie z dużymi prędkościami skrawania zapewnia wykonanie z pełnego materiału skomplikowanych części cienkościennych zgodnie $\mathrm{z}$ wysokimi wymaganiami dotyczącymi jakości wyrobów, jak również pozwala na skrócenie czasu wykonania wyrobu i uniknięcie kosztownego oprzyrządowania stosowanego w innych technologiach. Obecnie przy projektowaniu statków powietrznych dąży się do tego, aby zawierały one dużą liczbę elementów integralnych. Metoda frezowania z dużymi prędkościami skrawania umożliwia wykonanie części, które we wcześniej stosowanych technologiach musiały być łączone poprzez nitowanie, spawanie czy zgrzewanie [14]. Do tej grupy należy zaliczyć takie elementy jak: wręgi, żebra, podłużnice oraz pokrycia kadłuba i skrzydła. Zastosowanie techniki frezowania HSM ułatwia wykonanie cienkich ścianek, gdyż skraca ona czas kontaktu narzędzia z przedmiotem obrabianym i w konsekwencji zmniejsza się wpływ oddziaływania czynników siłowych i cieplnych wywołujących ugięcia sprężyste i plastyczne. 
W przemyśle lotniczym i kosmicznym części z metali lekkich są wykonywane poprzez usunięcie za pomocą frezowania nawet $98 \%$ materiału przygotówki. Frezowanie szybkie przenika do innych dziedzin, coraz częściej jest stosowane w przemyśle motoryzacyjnym do wytwarzania części ze stopów aluminium lub magnezu. Obróbka z dużymi prędkościami została zapoczątkowana we frezowaniu, ale zaadaptowana również w toczeniu, rozwiercaniu i wierceniu. Współczesne centra obróbcze są wielozadaniowe, w efekcie w jednej operacji realizuje się kilka złożonych zabiegów.

Doświadczenia własne uzyskane w wyniku badań nad zastosowaniem technologii HSM w wykonaniu struktur cienkościennych pozwalają na sformułowanie pewnych wskazań prowadzących do minimalizacji błędów kształtu oraz poprawy jakości powierzchni obrabianych części:

- należy stosować prędkość skrawania min. $850 \mathrm{~m} / \mathrm{min}$ : dla ścianek o grubościach 0,6-1 mm celowe jest skrawanie prędkościami ok. $1000 \mathrm{~m} / \mathrm{min}$ i głębokością skrawania ok. $0,2 \mathrm{~mm}$,

- należy przeprowadzić optymalizację parametrów skrawania ze względu na składową siły skrawania prostopadłą do frezowanej ścianki,

- podstawowym warunkiem poprawnej obróbki struktur cienkościennych, gwarantującym dobrą jakość powierzchni i zachowanie tolerancji kształtu, jest prawidłowy dobór odpowiedniego stosunku wysokości do grubości, mianowicie:

- dla ścianek bardzo cienkich stosunek wysokości do grubości powinien spełniać warunek < 15:1 (rys. 9.)

- dla ścianek o umiarkowanej grubości stosunek wysokości do grubości $<30: 1$

- dla ścianek grubych stosunek wysokości do grubości może być większy od 30:1.

- struktura konstrukcji winna być taka, aby wystąpiły usztywnienia zarówno poprzeczne, jak i wzdłużne, przy czym ich grubości mogą być różne (rys. 8.).

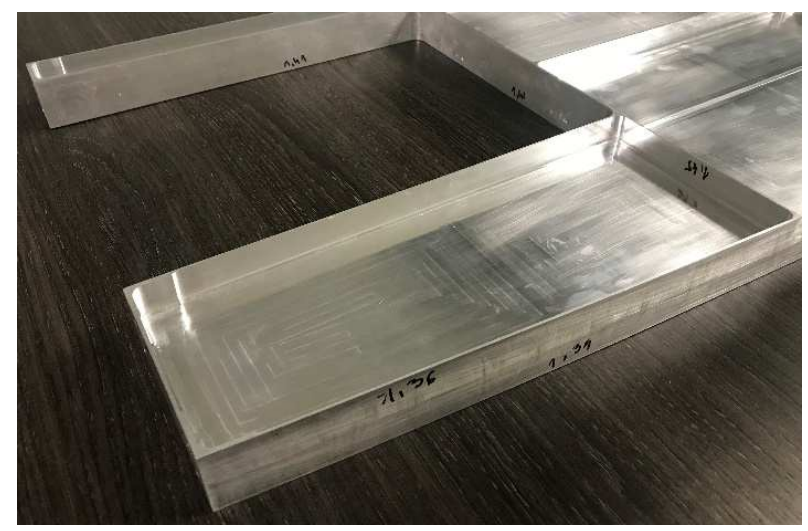

Rys. 9. Gotowa belka wzdłużna wykonana metodą HSM dla współczynnika wysokości ścianek do grubości < 15:1 
Liczba przejść we wszystkich przypadkach będzie uwarunkowana wymiarami ścianki i osiową głębokością skrawania. W celu zmniejszenia ugięcia ścianki podczas obróbki należało skrócić czas styku narzędzia z materiałem obrabianym, poprzez zastosowanie wysokiej prędkości obrotowej. Istotną rolę odgrywa stabilność narzędzia i obrabianej ścianki. W przypadku mało sztywnego podparcia frezowanego fragmentu przedmiotu cienkościennego należy zastosować frezowanie przeciwbieżne. Efekty frezowania można poprawić również poprzez frezowanie przeciwnych ścianek żebra z zachowaniem różnicy poziomów frezowania, co gwarantuje lepsze podparcie ścianki w punktach zmiany głębokości frezowania. Zaleca się, aby naddatek na obróbkę wykończeniową wynosił $0,2-0,5 \mathrm{~mm}$.

W przypadku ścianek o małych grubościach $(0,4-0,6 \mathrm{~mm})$ i dużych wymaganiach jakości powierzchni, konieczne jest zastosowanie wysokoobrotowych elektrowrzecion mocowanych dodatkowo na obrabiarkach i stosowanie małej głębokości skrawania. Szczegółowy opis strategii frezowania w techologii HSM zawarto w pracach $[8,14,15]$.

Obecnie zakres zastosowania technologii HSM znacznie rozszerza się poza przemysł lotniczy i technologia ta znajduje zastosowanie w innych dziedzinach przemysłu, co pokazano w tab. 1 .

Tabela 1. Zakres zastosowania technologii HSM we współczesnym przemyśle

\begin{tabular}{|l|l|l|}
\hline $\begin{array}{l}\text { Korzyści } \\
\text { technologiczne }\end{array}$ & Zakres zastosowań & Przykłady zastosowań w przemyśle \\
\hline $\begin{array}{l}\text { Duża objętościowa } \\
\text { wydajność obróbki }\end{array}$ & $\begin{array}{l}\text { Stopy metali lekkich, stale i } \\
\text { żeliwa }\end{array}$ & $\begin{array}{l}\text { Produkcja w przemyśle lotniczym i kosmicznym, } \\
\text { wytwarzanie narzędzi i form odlewniczych }\end{array}$ \\
\hline $\begin{array}{l}\text { Wysoka jakość } \\
\text { powierzchni }\end{array}$ & $\begin{array}{l}\text { Obróbka precyzyjna, } \\
\text { elementy specjalne }\end{array}$ & $\begin{array}{l}\text { Przemysł optyczny, precyzyjne części } \\
\text { mechaniczne, łopatki spiralne do sprężarek }\end{array}$ \\
\hline Małe siły skrawania & $\begin{array}{l}\text { Obróbka elementów z } \\
\text { cienkimi ściankami }\end{array}$ & $\begin{array}{l}\text { Przemysł lotniczy i kosmiczny, przemysł } \\
\text { motoryzacyjny, przemysł AGD }\end{array}$ \\
\hline $\begin{array}{l}\text { Transport ciepła } \\
\text { skrawania przez wiór }\end{array}$ & $\begin{array}{l}\text { Obróbka materiałów ze } \\
\text { ograniczeniem wpływu ciepła }\end{array}$ & Mechanika precyzyjna, stopy magnezu \\
\hline
\end{tabular}

\section{Wnioski}

Zastosowanie technologii High Speed Machining (HSM) do obróbki cienkościennych struktur samolotów jest możliwe dzięki precyzji stosowanych obrabiarek oraz dobrych właściwości obróbkowych stopów aluminium typu 7075. Odpowiedni dobór parametrów obróbki zapewnia niską chropowatość i małą falistość powierzchni. W przypadku obróbki ścianek o stosunku wysokości do grubości mniejszym niż 15, wpływ odkształcenia konstrukcji na dokładność wymiarową przedmiotu nie jest ważny i mieści się w zakresie tolerancji obrabiarki. W przypadku smukłych, wyższych ścianek wpływ ten zaczyna być widoczny i należy go zminimalizować poprzez wybór parametrów obróbki (posuw, głębokość skrawania). Zapewnienie dokładności kształtu wymaga odpowiedniego wyboru baz technologicznych i sposobu montażu przedmiotu obrabianego. 
W złożonych strukturach przestrzennych należy wprowadzić dodatkowe bazy zapewniające sztywność mocowania, a następnie usunąć je podczas operacji końcowych.

Ostateczne zastosowanie technologii HSM pozwala producentowi skrócić czas obróbki detalu. Przykładowo czas produkcji pokazanej belki (łącznie z przygotowaniem oprogramowania) wynosi 320 godzin. Można go skrócić do 15 godzin $\mathrm{w}$ produkcji seryjnej, stosując sprawdzony program kontroli i doświadczenie zdobyte podczas produkcji prototypu. Przy wykonawstwie prototypu czas obróbki zgrubnej belki wyniósł ok. 18 godzin, a wykończeniowej ok. 5 godzin, co w sumie zajęło ok. 23 godziny na wyprodukowanie belki przy zastosowaniu technologii HSM. W przypadku zastosowania technologii klasycznej, czas wykonania belki jest kalkulowany na 141 godzin.

Wykonana część jest integralną konstrukcją zastępującą obecne metody wytwarzania tego samego elementu poprzez obróbkę plastyczną poszczególnych części (30 lub więcej części), a następnie łączenie ich za pomocą elementów złącznych. Całkowity czas produkcji poszczególnych elementów belki był ponad 6 razy dłuższy niż czas produkcji z wykorzystaniem metody HSM. Jednocześnie z korzyściami wynikającymi ze skrócenia czasu produkcji ramy, zaletą proponowanej technologii jest również jakość i dokładność wykonania, a także chropowatość uzyskanych powierzchni.

\section{Podziękowanie}

The works were carried out within the project "699757/SAT-AM" - Work programme topic: JTI-CS2-2015-CPW02-AIR-02-07. More Affordable Small Aircraft Manufacturing; Airframe itd. Grant Agreement No: CS2-AlR-GAM-2014-2015-01 (annex III) co-financed by Horizon 2020 Clean Sky 2. Special thanks go to the teams from: Instytut Lotnictwa, SZEL-TECH Szeliga Grzegorz, Zakłady Lotnicze Margański\&Mysłowski, PZL Mielec, CIRA, Eurotech, Metrol and Ultratech.

\section{Literatura}

1. Brzoska Z., Statyka i stateczność konstrukcji prętowych i cienkościennych, PWN, Warszawa 1965.

2. Fellipa C.A., Introduction to finie element methods, Dep. of Aerospace Eng. Sci. Bouilder, Colorado 2006.

3. Fellipa C.A., Nonlinear finite element methods, Dep. of Aerospace Eng. Sci. Bouilder, Colorado 2001.

4. Kopecki T., Stany zaawansowanych deformacji w projektowaniu cienkościennych ustrojów nośnych, Oficyna Wydawnicza PRz, Rzeszów 2010.

5. Kopkowicz M., Wytrzymałość materiałów. Laboratorium, Oficyna Wydawnicza PRz, Rzeszów 2006.

6. Lundblad M., Influence of Cutting Tool Geometry on Residual Stress in the Workpiece, Proc. Third Wave Advant Edge User's Conferece, Atlanta, GA, Paper 7(2002). 
7. Shet C., Deng X., Residual Stresses and Strains in Orthogonal Metal Cutting, Int. J. Machine Tools Manuf., 43/6(2003), 573-587.

8. Kuczmaszewski J., Pieśko P., Zawada-Michałowska M., Influence of Milling Strategies of Thin-walled Elements on Effectiveness of their Manufacturing, Procedia Engineering (2017), 182:381-186.

9. Adamski W., Manufacturing development strategies in aviation industry, Advances in Manufacturing Science and Technology, Vol. 34, nr 3(2010), 73-84.

10. Bałon P., Szostak J., Kiełbasa B., Rejman E., Smusz R., „Application of High Speed Machining Technology in Aviation", $21^{\text {st }}$ International ESAFORM Conference on Material Forming (2018).

11. Bałon P., Rejman E., Smusz R., Szostak J., Kiełbasa B., „High Speed Milling in thin-walled aircraft structures", Applied Computer Science, Vol. 14, nr 2(2018), pp. 82-95.

12. Shih A.J., Yang H.T.Y., Experimental and Finite Element Predictions of Residual Stresses Due to Orthogonal Metal Cutting, Int. J. Num. Meth. Eng., 36(1993), 1487$-1507$.

13. Mativenga P.T., Hon K.K.B., An experimental study of cutting force in high speed end milling and implications for dynamic force modelling, Journal of Manufacturing Science and Engineering, 127, 2(2005), 251-261.

14. Adamski W., Wpływ nowych technik wytwarzania na konstrukcję samolotu, Mechanika, nr 12(2015).

15. Włodarczyk M., Analiza wpływu sił skrawania oraz zamocowania na poziom naprężeń w aspekcie grubości ścianek wybranej konstrukcji kieszeniowej, Postępy Nauki i Techniki, nr 8(2011) Politechnika Lubelska. 
